\title{
Host-microbe interactions in the gut: lessons learned from models of inflammatory bowel diseases
}

\author{
Eytan Wine*
}

\begin{abstract}
The mammalian gut is the richest immune organ in the body and serves as a central location for immune system development, processing, and education. Inflammatory bowel diseases (IBD) provide excellent models for studying both innate and adaptive responses to gut microbes and the host-immune system - microbe interactions in the gut. Microbes are linked to almost all of the known disease-associated genetic polymorphisms in IBD and are critical mediators of environmental effects (through food, hygiene, and infection). Human and animal-based research supports the central role of microbes in IBD pathogenesis at multiple levels. Animal models of IBD only develop in the presence of microbes, and co-housing mice that are genetically susceptible to gut inflammation with normal mice can lead to the development of bowel injury. Recent advances in research technologies, such as deep-sequencing that enables detailed compositional analyses, have revolutionized the study of hostmicrobe interactions in the gut; however, knowing which bacteria are present in the bowel is likely not sufficient. The function of the microbiota as a community is recognized as a critical factor for gut homeostasis. Animal models of IBD have provided critical insight into basic biology and disease pathogenesis, especially regarding the role of microbes in IBD pathogenesis. Although many of these recent discoveries on host-microbe interactions are not yet applied to patient care, these basic observations will certainly revolutionize patient care in the future. Using such data, we may be able to predict risk of disease, define biological subtypes, establish tools for prevention, and even cure IBD using microbes or their products. A broad spectrum of therapeutic tools spanning from fecal transplantation, probiotics, prebiotics, and microbial products to microbe-tailored diets may supplement current IBD treatments.
\end{abstract}

\section{Introduction}

\section{Microbial involvement in health and disease (focus on inflammatory bowel diseases)}

Immediately after birth the entire gut is populated by large numbers of microbes. These extend from the mouth to the anus with increasing numbers from the proximal to distal bowel. A total of 1000-1500 individual microbial species, many of which are nonculturable, are thought to inhabit the human gut. The total number of microbes in the intestine is estimated to be
100 trillion, outnumbering the number of somatic human cells by a factor of 10:1. The largest concentration is found in the terminal ileum and colon (locations most commonly affected in inflammatory bowel diseases (IBD)), where up to $10^{12}$ microbes can be found in every millilitre of bowel content (Backhed et al. 2012). This concentration is the highest achievable, even under ideal laboratory conditions, demonstrating the high level of mutual adaptation and symbiosis existing between microbes and the mammalian gut. The critical role and importance of the intestinal microbiota is demonstrated by the collective metabolic activity,
Division of Pediatric Gastroenterology and Nutrition, Departments of Pediatrics and Physiology, University of Alberta, Edmonton, AB, Canada

*Corresponding author: Eytan Wine/wine@ualberta.ca
Submitted 29 July 2014

Accepted 1 October 2014

Available online 1 October 2014

LymphoSign Journal 1:61-76 (2014)

dx.doi.org/10.14785/lpsn-2014-0014 
exceeding that of the liver, and a collective microbial genome, termed "microbiome", which includes $2-3$ million genes, about 150-fold higher than the human genome (Ding and Schloss 2014). This emphasizes the huge potential for this accessory organ in the human superorganism. As a result, the collective microbiome has the capacity to undertake diverse metabolic tasks, many of which are critical for nutrition, immune system function, and homeostasis (Eckburg et al. 2005; Qin et al. 2010).

Microbes have been clearly defined as critical contributors to the pathogenesis of IBD (including 2 main clinical forms: Crohn disease (CD) and ulcerative colitis (UC)), as illustrated in Figure 1 (Sartor 2008; Manichanh et al. 2012; Kostic et al. 2014; Wine 2014). This is supported by observations in patients such as the presence of most IBD-related inflammation in the distal small bowel and colon (Levine et al. 2011), which inhabit the highest concentration of bacteria in the gut; a resolution of symptoms with diversion of fecal flow (through a surgical ileostomy) and a recurrence of symptoms with reinfusing the bowel contents (D'Haens et al. 1998). In addition, the use of antibiotics, and more recently probiotics (defined as live microorganisms that benefit the host when provided in sufficient amounts), have also suggested that microbes might be involved in pathogenesis (Shanahan 2000; Huynh et al. 2009; Gareau et al. 2010; Turner et al. 2014). Some of the most convincing evidence is found in animal studies, mainly because animals reared without bacteria, such as germ-free mice, do not develop bowel inflammation when challenged with different disease models and that exposing these animals to bacteria induces disease (Knights et al. 2013). Even basic physiologic gut functions, such as the enteric nervous system and motility, are driven by microbes likely through interactions with macrophages and other immune cells in the muscularis layer (Muller et al. 2014). However, despite advances in research methods over the last few years, insights into disease mechanisms and understanding the involvement of bacteria in pathogenesis, as well as utilizing microbes for treating patients, are still lacking or are in the early stages of development.

\section{Microbes and IBD pathogenesis}

It is important to recognize that as IBD are complex, multifactorial groups of disorders, patients with IBD do not follow a single etiology and pathogenesis. Rather, each individual patient is more likely to have a private set of circumstances leading to a similar phenotype. Nevertheless, the traditional model for IBD pathogenesis, suggesting that disease develops in genetically susceptible individuals as a result of an aberrant immune response to environmental triggers, is well supported and accounts for the diversity of causes and biological processes leading to bowel inflammation. Within this

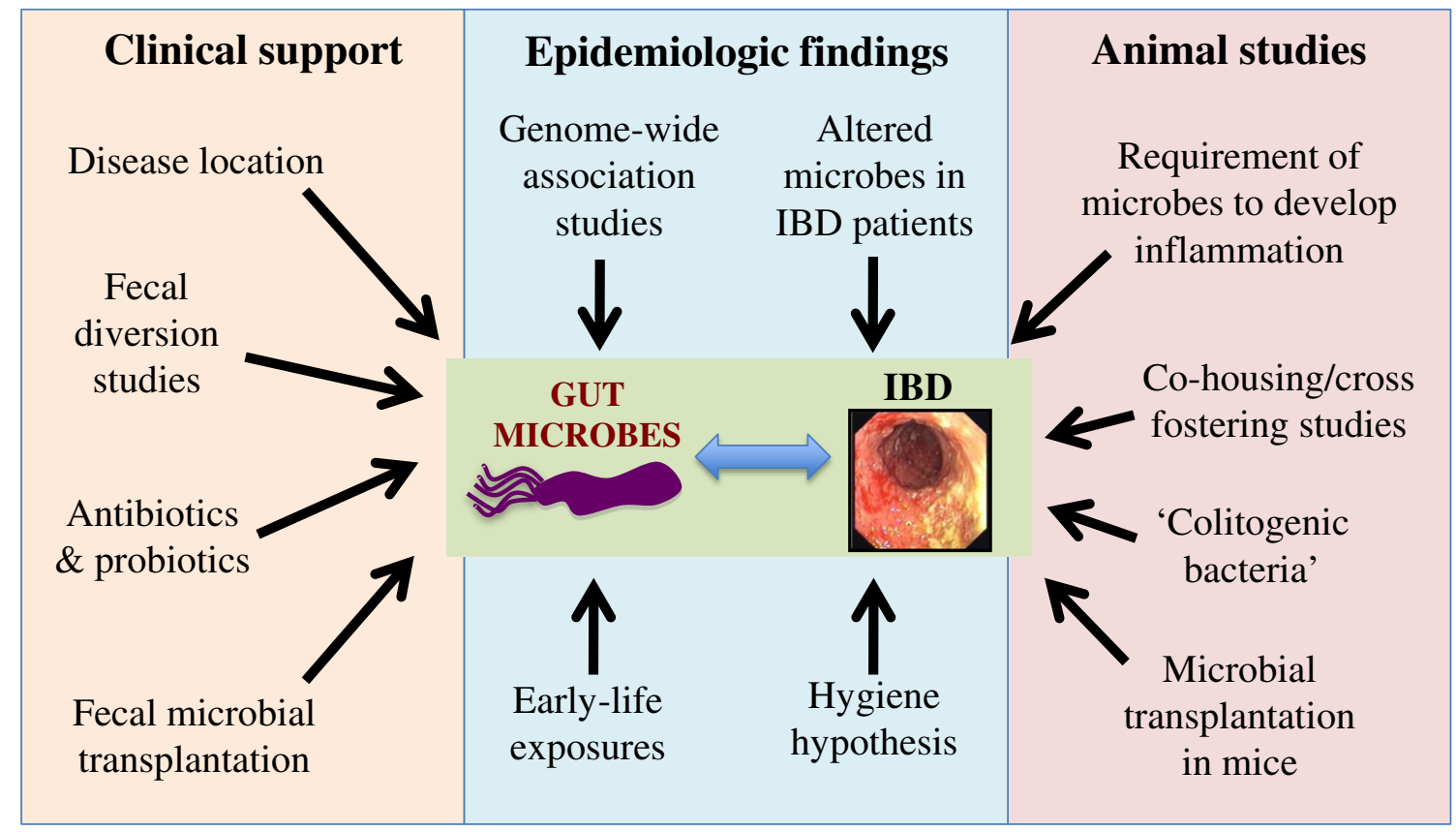

Figure 1: Multiple lines of evidence supporting the involvement of microbes in the pathogenesis of inflammatory bowel diseases. 
context, recent literature supports involvement of microbes in all aspects of disease (Knights et al. 2013). Most of the 163 genes linked to IBD in recent studies relate to host-microbe interactions, likely leading to effects on microbial composition and immune response to microbes throughout life (Jostins et al. 2012). Environmental exposures further influence microbes throughout development in a way that could contribute to the etiology of IBD. Many IBD-associated exposures present during early life including mode of delivery, exposure to breast milk, location of upbringing, and immigration during childhood; these associations are likely related to the hygiene hypothesis (Figure 2; Shaw et al. 2010; Castiglione et al. 2012; Shanahan 2012; Ng et al. 2013; Perez-Cobas et al. 2013). An example for the involvement of the hygiene hypothesis in IBD pathogenesis is a potential protective role against IBD for childhood helminth infection (Chu et al. 2013) as well as some controversial evidence supporting helminths as therapy for active IBD (Garg et al. 2014). Later in life, infection, nutrition, and air pollution (Beamish et al. 2011) also affect microbes and have been linked to IBD. Conversely, inflammation itself can impact microbes, likely in a way that is detrimental to the host; this could create a vicious cycle where inflammation and microbes could escalate gut disease (Wine 2014). Multiple animal models also support the involvement of microbes in inducing intestinal inflammation, as all mouse models of IBD require the presence of microbes to develop their phenotype. An excellent example for this is the TRUC model (Tbet ${ }^{-/-} \mathrm{RAG}^{-/-}$ double knock-out (KO) mice that develop a UC-like phenotype). These mice spontaneously develop colitis (but only in the presence of bacteria) through regulation of tumour necrosis factor (TNF)- $\alpha$ by dendritic cells and disruption of the epithelial barrier. One of the curious findings of this study was that colitis was communicable in these mice, as cohousing (healthy and sick mice living in the same cage) or cross-fostering (switching pups between dams from different groups) of the double-KO mice with genetically normal (wild type (WT)) mice led to colitis in the normal mice, suggesting that "colitogenic" microbes develop in the double-KO environment and then transfer the disease independently (Garrett et al. 2007). For all of these reasons, better understanding the role of microbes in disease pathogenesis and targeting microbes at various stages may lead to novel treatments and possibly the ability to prevent IBD.

\section{Innate immunity and host defence: bridging between the host and microbes}

Innate defences in the gut are diverse and complex, and they are critical for homeostasis and the prevention of disease (Belkaid and Hand 2014). It is important to
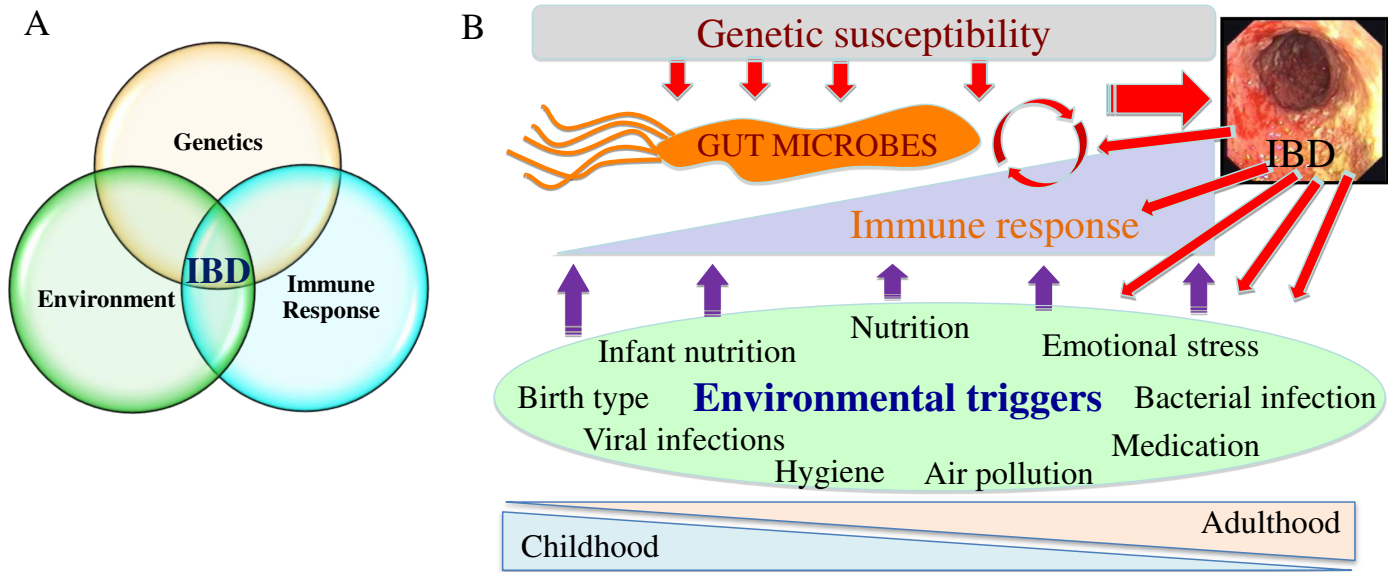

Figure 2: The traditional model focuses on the interplay between host genetics, environmental exposures, and an aberrant immune response, leading to IBD (A). The proposed comprehensive model takes into account the progression of immune response in the gut and the role of exposures during different stages of life, with specific emphasis on the involvement of microbes in all stages. Genetic susceptibility is always present and relevant; however, environmental exposures and triggers vary with age (early life events are on the left). These insults, on the appropriate genetic background, lead to inflammation through changes in microbes. Once IBD develops it can lead to a positive feedback loop with inflammation, which further affects microbes and various exposures (B). (Modified from Wine (2014).) 
recognize that innate immunity extends beyond immune cells and pattern recognition molecules (PRMs). Additional layers of host defence including the epithelial monolayer and mucins as well as $\mathrm{pH}$, motility, and digestive factors should all be seen as part of the global host innate defences. In fact, even the gut microbes themselves are pivotal to host defence, as demonstrated in germ-free animals (Figure 3). The main physical portion of the intestinal barrier is composed of a single layer of dynamic and constantly renewing epithelial cells. The epithelial barrier integrity is maintained mainly by apical junctional complexes (AJC; includes tight junctions and adherens junctions), which form a continuous fence-like ring around cells (Camilleri et al. 2012). Pathogens have developed specialized virulence traits to target AJC proteins, the cytoskeleton, and related signalling pathways, thus enabling them to disrupt this critical innate defence layer and penetrate into the submucosal layers. Additional extracellular protection is maintained by factors secreted into the lumen, including anti-microbial factors (e.g., defensin, cathelicidin), immunoglobulin (Ig)-A, and mucins. In fact, when functioning normally, all of these factors are capable of maintaining a sterile environment within the dense mucus layer covering the epithelium and within intestinal crypts (Everard et al. 2013; Shan et al. 2013; Cupi et al. 2014). Central to production of these factors are goblet cells (produce mucins; located throughout the bowel epithelium and between absorptive epithelial cells) and Paneth cells (produce antimicrobial factors; located at the base of the crypts of the small bowel), (Peterson and Artis 2014; Shanahan et al. 2014). Paneth cell function is dependent on autophagy, as a common IBD risk allele in the autophagy gene ATG16L1 results in an abnormal phenotype of Paneth cells linked to microbial handling in both mice and humans (Cadwell et al. 2010; Lassen et al. 2014; VanDussen et al. 2014). A potential link between autophagy and antimicrobial activity of Paneth cells likely involves endoplasmic reticulum (ER) stress, as patients with Crohn disease carrying the ATG16L1 risk allele had increased ER stress linked to presence of pathogenic adherent-invasive Escherichia coli in mucosal biopsies (Deuring et al. 2014).

PRMs, located on and within epithelial and immune cells in the gut, have a critical role in maintaining tolerance and homeostasis. They serve as sensors of microbial motifs, termed microbe-associated molecular patterns (MAMPs), usually leading to the production of cytokines and downstream activation of transcription factors, such as nuclear factor (NF)- $\kappa B$ (Santaolalla

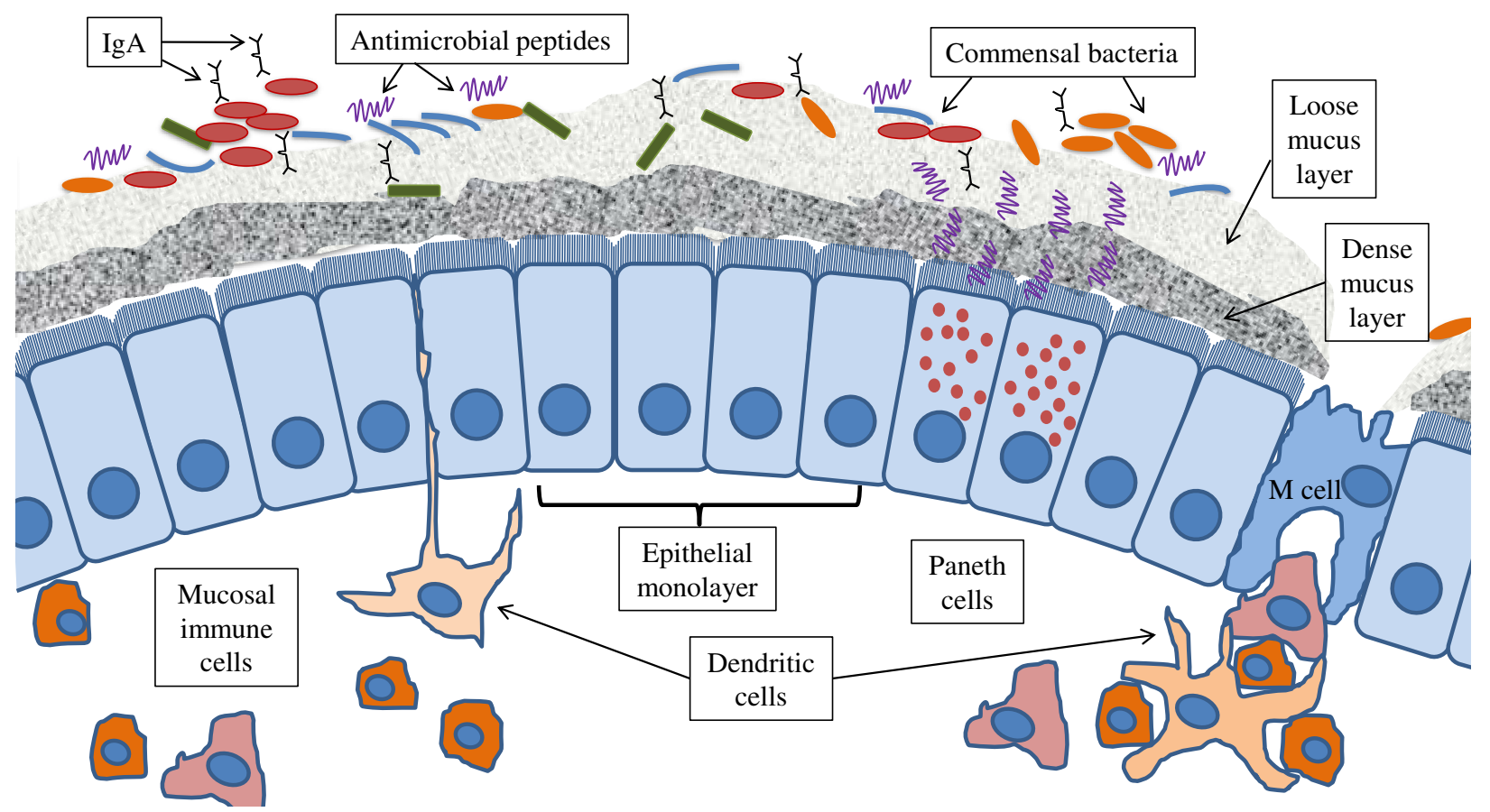

Figure 3: The epithelial monolayer serves as the backbone of the gut barrier; however, the barrier is further enhanced by additional luminal factors, such as $\lg \mathrm{A}$, antimicrobial peptides, and the commensal microbiota as well as the subepithelial immune cells. Paneth cells control microbial colonization through secretion of antimicrobial peptides. M cells and dendritic cells allow for microbial sampling and immune processing and mucosal immune cells balance host responses through pro-inflammatory and counter-regulatory activities (e.g., regulatory T cells). 
and Abreu 2012). Interactions between microbes and these pathways result in the induction of proinflammatory cytokines and chemokines in some cases, or down-regulation of these factors and expression of inflammation-suppressing cytokines in other cases (Neurath 2014). Host immune pathways have evolved to tolerate commensal organisms and defend against pathogens through carefully controlled epithelial responses to microbial agents. In contrast, response to pathogens leads to inflammation, necessitating countermechanisms to limit the destructive consequences of immune activation. This diverse array of ligands, receptors, pathways, and the gene products involved, many of which interact with each other, contributes to the flexibility and regulation of immune responses, and it is likely disrupted in individuals with IBD.

It is also important to recognize the diversity of host cell types implicated in IBD pathogenesis. In addition to epithelial cells, neutrophils and other immune cells play critical roles. For example, neutrophil- and macrophage-derived cytokines are increased in IBD patients and animal models (Knutson et al. 2013; Wine et al. 2013). In fact, fecal calprotectin and myeloperoxidase, neutrophil products linked to bowel inflammation, are increased in healthy twins of IBD patients, suggesting a fundamental role for neutrophils in disease pathogenesis (Zhulina et al. 2013).

PRM groups include the toll-like receptors (TLRs), nod-like receptors (NLRs), retinoic acid-inducible gene I-like receptors (RLRs), C-type lectin receptors (CLRs), and AIM-2-like receptors (ALRs) (Hussey et al. 2009). A review of all PRMs and MAMPs is beyond the scope of this paper. However, several pathways of particular relevance to IBD models are highlighted below. NLRs are broadly classified as those that activate "proinflammatory" transcription factors and cytokine production (e.g., NF- $\mathrm{kB}$ ) and those that mediate assembly and activation of the inflammasome (described below). NOD2, the first identified and still most prominent IBD susceptibility gene, is an example for the former group of NLRs, with critical, but still not completely clear, roles in regulation of host defence and immune homeostasis in the gut (Corridoni et al. 2014).

The inflammasome has also attracted attention in many immune-mediated conditions, including IBD. Although various triggers of inflammasome activation have been identified, highlighting its fundamental role in response to danger signals, microbes remain some of the best-defined activators (Ayres 2013). As a result of inflammasome assembly, pro-inflammatory cytokines [interleukin (IL)-1 $\beta$ and IL-18] are activated (Lamkanfi and Dixit 2014). This can lead not only to an anti-microbial effect, but can also cause "collateral damage" when over-activated, as seen in autoinflammatory conditions (Ratsimandresy et al. 2013). We have recently demonstrated this critical balance in inflammasome responses using an infectious model of IBD in mice. Mice lacking NACHT, LRR, and PYD domains-containing protein (NLRP)-3, a key component of the NLRP-3 inflammasome, were more susceptible to infection with the mouse pathogen Citrobacter rodentium, which also led to colitis, relative to infected WT mice. Administration of IL- $1 \beta$ to the NLRP- $3^{-1-}$ mice, in an attempt to overcome this defect, protected these mice and reduced bacterial colonization, as expected. What we did not expect was a detrimental effect of IL- $1 \beta$ administration on WT mice, where bacterial colonization and tissue damage were worsened by providing IL-1 $\beta$ (Alipour et al. 2013). This highlights the importance of appropriate and balanced activation of innate responses in the bowel to enable effective elimination of bacteria while preventing excessive damage by immune activation, which may be relevant to IBD.

The intestinal flora has a dynamic relationship with the host epithelial innate response. Microbiota do not generate inflammation in most cases; they can, however, induce the expression of antimicrobial factors that inhibit the growth of bacterial pathogens or elicit antiinflammatory responses to minimize damage (O'Hara et al. 2006; Vaishnava et al. 2008). For example, RegIII (an antimicrobial C-type lectin) modulates commensalepithelial interactions by physically limiting surface contact between organisms and cell surfaces and through binding carbohydrate motifs on the peptidoglycan bacterial wall (Vaishnava et al. 2011). In fact, exogenous administration of LPS or flagellin is able to restore TLR4 or TLR5 signalling in antibiotic-treated mice by up-regulating the expression of RegIII $\gamma$, which then decreases bacterial colonization, supporting a protective role for antimicrobial factors through engagement of PRMs (Brandl et al. 2008).

However, many pathogens have developed countermechanisms to evade and bypass host recognition and down-regulate and interfere with inflammation. On the other hand, host responses leading to inflammation, including diarrhea, barrier breakdown, and colonic hyperplasia, may actually benefit pathogens by enhancing their colonization, survival, and spread (Klapproth 
et al. 2005; Baxt et al. 2013; Benjamin et al. 2013; Czuczman et al. 2014; Peterson and Artis 2014).

\section{Microbial composition and function in IBD patients}

In the past, most studies used culture-based methods to characterize microbiota, which was limited by the fact that the majority of bacteria were not culturable. Later advances in sequencing technologies, initially focusing on the bacterial $16 S r R N A$ gene (conserved in all prokaryotes and therefore useful for compositional analysis), and more recently using metagenomics (enabling sequencing of the complete microbial genetic material), have provided robust data on microbial composition and function in patients, especially in those with IBD. In addition, there have been advances in microbial culture and isolation techniques, such as culturomics (Gouba et al. 2014). An early key comprehensive study used tissue samples collected during endoscopy and stool to demonstrate major shifts in microbes in IBD patients relative to controls (Peterson et al. 2008). A landmark study by Qin et al. (2010) sequenced the full metagenome of 124 Europeans, which provided the first detailed human gut microbial catalogue. This was based on full sequencing of all genetic material in the stool (i.e., metagenomics) with a total of 576 gigabases sequenced, revealing 3.3 million microbial genes. Twenty-five of these individuals suffered from IBD, and these patients showed clear separation from the healthy controls, with reduced microbial richness (defined as fewer microbial genes). This suggests that IBD patients have, in addition to shifts in composition, reduced microbial metabolic potential and diversity, although it does not clarify whether this is a cause or result of inflammation (Qin et al. 2010). Further advancements, just published by the same research initiative (termed MetaHit - Metagenomics of the Human Intestinal Tract, as part of the international Human Microbiome Project) (Gevers et al. 2012), present a catalogue containing close to $10^{6}$ integrated microbial genes and using more than 1250 patient samples. This study will not only serve as a valuable reference for future metagenomic studies but also suggests country-specific gut microbial signatures, which are yet to be clearly defined ( $\mathrm{Li}$ et al. 2014). The term enterotypes was coined to summarize patterns of compositional shifts in IBD patients, where dominance of specific taxa and functional capacity appear to characterize various clinical settings, but such a simplified summary of extensive datasets comes with the price of loss of detail (Arumugam et al. 2011). Some data on the microbiome in children with IBD are also available; using stool collected during early stages of disease from a cohort of North American children hospitalized for severe acute UC, we demonstrated a reduction in microbial diversity in these patients relative to healthy controls. Interestingly, we also found that the number of bacterial species (i.e., microbial richness) found on day 3 of intravenous corticosteroid treatment was lower in those patients that eventually failed standard treatment and required second line therapy or colectomy, suggesting that microbial patterns could be used as a clinical predictor of response to therapy (Michail et al. 2012).

It is also important to recognize that although most of the current research focuses on bacterial involvement in IBD pathogenesis there is clearly a role for other microbes including helminths, fungi, and viruses. Recent insights into the interplay between viruses and helminths reveal not only the role of these microorganisms in immune regulation but also that many of these effects are independent of microbes (Osborne et al. 2014; Reese et al. 2014; Veldhoen and Heeney 2014). Further attention to involvement of understudied nonbacterial microbiota in IBD pathogenesis is therefore required.

\section{Advancements in research tools used to study microbes and their effects}

Exciting advances in research methods over the last decade, with the development of a multitude of "omics"-based analyses, have revolutionized hostmicrobe research (Wu and Lewis 2013; Goodrich et al. 2014). These methods are now cheaper, more robust, and more available than ever before. Although most studies to date have focused on sequencing the bacterial $16 S$ rRNA gene, metagenomics enables the study of the entire genetic potential of gut microbiota (including fungi, viruses, and even bacteriophages) (Dalmasso et al. 2014), and metabolomics proved information on products of microbial metabolism and function. These methods have added critical layers of data to our understanding of this fascinating ecosystem (Wu and Lewis 2013). Such approaches will advance the understanding of detrimental alterations in microbial composition (dysbiosis), which are associated not only with IBD but also with many other chronic immune-mediated conditions outside of the gut (Nicholson et al. 2012). 
A few examples of recent host-microbe studies are presented to illustrate the potential for this research and how it may advance science and impact on patient care in the future. Using a combination of microbial sequencing with analyses of specific pathways and metabolites (through metabolomics), Machiels et al. (2013) demonstrated that patients with UC have specific reductions in butyrate-producing bacteria (including Faecalibacterium prausnitzii, also shown to be protective in CD patients (Sokol et al. 2008) and Roseburia hominis). These compositional changes were associated with reductions in short-chain fatty acids, suggesting that complementing patients with these bacteria may benefit them (Machiels et al. 2014). An excellent example of how microbes can indirectly affect host factors related to chronic disease is shown using a model for type- 1 diabetes, the non-obese diabetic (NOD) mouse. Interestingly, male NOD mice are protected from developing diabetes, suggesting a role for sex hormones, but this protective effect was absent in germ-free mice, implicating microbial involvement. Transfer of microbes (or, alternatively, $\mathrm{T}$ lymphocytes from mice housed with microbes) from male mice to females maintained this protective effect, suggesting that microbes induce autoimmunity through sex hormones and T cells (Markle et al. 2013). Another mouse model demonstrated the long-term effects of bacterial infection on the gut, even long after the infection is cleared. These effects included changes in microbial composition and inflammation and presented a potential challenge in identifying microbial causes of IBD, as the culprit bacteria may be long gone by the time patients develop clinical symptoms (Chassaing et al. 2014).

Another fascinating study supporting a complex role for microbes in disease pathogenesis utilized germ-free mice colonized with human stool samples. Stool samples from 371 Malawian twins, $43 \%$ of whom were discordant for the development of Kwashiorkor (severe protein malnutrition), were analyzed. The authors demonstrated limited microbial metabolic potential in malnourished infants as well as induction of severe weight loss in germ-free mice transplanted with microbes isolated from Kwashiorkor infants (but not their well-nourished twins). This effect was not rescued by nutrition alone, further supporting a direct role for microbes. Dramatic shifts in metabolic pathways were also observed in these mice, highlighting potential functional mechanisms (Smith et al. 2013). Together, these studies offer a glimpse into future host-microbe research and how such techniques could be applied to elucidate microbial involvement in IBD.

\section{Using host-microbe research to advance patient care}

Most current treatments for IBD patients use immunosuppressive drugs such as corticosteroids, thiopurines, methotrexate, or anti-TNF monoclonal antibodies (e.g., infliximab and adalimumab). Such medications expose patients to increased risks of infections and other adverse events including cancer. In addition, these nonspecific treatments do not target the original causes of disease but are rather used to control the host inflammatory response. However, there are some established microbe-focused therapies used in treating IBD, including antibiotics and probiotics, but these are not considered to be as effective as drugs that manipulate the immune response (Khan et al. 2011; Whelan and Quigley 2013). One potential explanation for the reduced efficiency of probiotics or antibiotics is that current tools to select the correct treatment for each patient are lacking (Levine and Turner 2011). Some experience with fecal microbial transplantation in IBD has also been demonstrated, although results are still controversial and may be considered risky especially in children (Anderson et al. 2012; Kao et al. 2014). Of interest is the use of nutritional therapy, an effective and attractive treatment for pediatric $\mathrm{CD}$, which could act through altering microbes and eliminating adverse changes in microbes in response to food (Tjellstrom et al. 2012; D'Argenio et al. 2013; Levine and Wine 2013). Several concepts of microbe altering or targeted approaches to treat IBD patients in the future are presented as potential future developments in this field.

\section{Microbial composition-guided therapies}

Analyses of microbial composition and (or) function may reveal their role in pathogenesis or, at the very least, it could provide disease biomarkers. As these data are being collected, they could, over time, lead to the development of computer-assisted biological pathway analyses that could assist in sub-classifying disease type, predicting prognosis, and guiding treatment. A relatively simple example, mentioned previously, is the reduced microbial richness observed in children with severe UC as a predictor of failure to respond to intravenous corticosteroids (Michail et al. 2012). Such approaches could be coupled with multiple omics analyses, which could then lead to microbe-guided personalization of treatment (Chen et al. 2012). With such data available, one could consider either complementation of the gut flora with microbes thought to be beneficial that 
are found to be missing in an individual patient or tailored antibiotics (or other specific anti-microbials such as microbe-binding antibodies), targeted to bacteria found in excess that are thought to be harmful. An alternative approach to modifying microbes and their function could be through diet, which impacts microbes significantly (see below). As technology continues to advance, these ground-breaking approaches will penetrate further into patient care.

\section{Manipulating host immune responses using microbes and nutrition}

Microbes are usually referred to as propagators of disease, but innovative uses of microbes could potentially serve much more novel functions. Effects of microbes on the development, "education", and maintenance of host immunity are well established and are the basis for the hygiene hypothesis (Bach 2002). Such insights could be used for therapeutic applications. One example demonstrated by Atarashi et al. (2013) used chloroform treatment to select microbiota isolated from human stool; these bacteria were then able to enrich the $\mathrm{T}_{\text {reg }}$ capacity after passage through a few generations of germ-free mice. The investigators were able to isolate specific Clostridia species that maintained higher $\mathrm{T}_{\text {reg }}$ responses and protected mice from an experimental colitis model (Atarashi et al. 2013). In another study, short-chain fatty acids (end products of microbial metabolism, which are usually considered to be beneficial to the gut) were found to regulate $\mathrm{T}_{\text {regs }}$ and prevent $\mathrm{T}$-cell transfer-colitis, possibly through similar mechanisms (Smith et al. 2013). B cells are also affected by microbes as early development and recombination of immunoglobulin receptors on early B-lineage takes place in the gut lamina propria in response to microbial signals (Wesemann et al. 2013). In fact, microbes have also been shown to activate sensory neurons in the skin, leading directly to pain and inflammation (Chiu et al. 2013).

One important additional approach used to manipulate microbes and change bowel homeostasis is through nutrition. Human studies have shown dramatic changes in microbes and their function with controlled dietary modifications (Wu et al. 2011; David et al. 2014). Changes in nutrition, such as the exclusive nutritional therapy mentioned previously, can significantly alter microbes and their effects. Some of these alterations are immediately relevant to clinical settings including atherosclerosis, metabolic syndrome, and
IBD (Tremaroli and Backhed 2012; Ridaura et al. 2013; Tang et al. 2013; Winter et al. 2013). An excellent example for this is demonstrated by the promotion of growth of mouse colitogenic bacteria, Bilophila wadsworthia, in response to saturated milk fat through taurine-conjugation of bile acids by the milk fat. This then leads to an increase in organic sulphur, which promotes growth of these bacteria leading to colitis (Devkota et al. 2012). In another very recent example that focused on the role of microbes in intestinal cancer development (Arthur et al. 2012) altering microbes with antibiotics, or even providing microbial metabolites, effectively protected mice susceptible to colon cancer from DNA mismatch repair, which is a leading cause of human colon cancer (Belcheva et al. 2014).

\section{Microbes and host genetics}

Host genetic factors are central to interactions with microbes and can be used to direct therapy. Microbes have extensive effects on host expression profiles, as exemplified in a study showing changes in the expression of thousands of genes when germ-free mice were exposed to bacteria and the most dominant changes were found in the small bowel including changes in energy harvesting and immunity (Larsson et al. 2012). In a more personalized approach, specific bacteria could be used to induce specific pathways and could be developed as targeted treatments. An excellent example for how defining one's "immune tone" could impact response to treatment is demonstrated through macrophage responses to Mycobacterium tuberculosis. Research in both humans and animals has shown that heterozygosity for the leukotriene gene $L T A 4 H$ is optimal for effective host defence against Mycobacteria, as homozygous low LTA4H activity leads to macrophage killing by mycobacteria, whereas homozygous $L T A 4 H$ high activity results in an exaggerated TNF response and macrophage necrosis, leading to the same final result of macrophage death and progressive infection. Having this information available could direct treatment by increasing antimicrobials in the former or enhancing immunosuppression (e.g., anti-TNF treatment) in the latter (Tobin et al. 2012; Roca and Ramakrishnan 2013). A potential specific application was demonstrated by another recent study, focused on IL-1 and M. tuberculosis, which suggested that host-directed immunotherapy with prostaglandin E2 agonists could compensate for excessive interferon (IFN) $-\gamma$ and protect mice from infection; this could be applied to humans with reduced IL-1 or excessive IFN activity (Mayer-Barber et al. 2014). 


\section{Fecal microbial transplantation (FMT)}

FMT has attracted much attention and controversy over the last few years, especially with the publication of a randomized-controlled trial using FMT to treat Clostridium difficile infection. This study was terminated prematurely, owing to profoundly favourable outcomes in the FMT-treated group (81\% cure vs. $31 \%$ in vancomycin-treated controls) (van Nood et al. 2013). In contrast, data on FMT in IBD are still lacking, although several studies have been published. A metaanalysis, published in 2012, identified 17 uncontrolled studies, 9 of which were case series or case reports, and in 8 cases FMT was used to treat infection in IBD patients, mainly $C$. difficile. Of the 41 patients included in the reviewed studies, data were available for 25 patients of which 19 improved (Anderson et al. 2012). More recently, Kunde et al. (2013) published an open label study on 10 children with moderate-severe UC. The children were treated with FMT, 5 daily enemas, and 6 of 9 who completed the study showed a response at 1 month, but this effect persisted in only 3 of the 9 patients at 3 months (Kunde et al. 2013). Although these studies are still small, they do not present the same promise FMT has shown in treating C. difficile infection, but it is possible that better results will be achieved in the future with appropriate patient selection guided by microbe analyses. However, much of the leading research on FMT is currently demonstrated using animal studies, employing germ-free mice colonized with human microbiota (another form of "humanized mice"). In one such study mice were transplanted with stool microbes from twins discordant for obesity. Those receiving microbes from the obese human twin accumulated fat, whereas those exposed to "lean stool" from a lean twin did not, implicating a role for microbes in fat deposition. Furthermore, cohousing lean-FMT with obese-FMT mice appeared to be protective to the obese FMT-exposed mice, suggesting that microbes from the lean environment have an invasive potential and can displace other bacteria (as confirmed by longitudinal microbial analyses in this study). Finally, the ability of "lean bacteria" to be protective is overridden when mice are exposed to a high-fat diet, suggesting complex interactions between microbial communities, metabolism, and diet (Ridaura et al 2013).

\section{Concluding remarks}

There certainly have been dramatic advances in hostmicrobe research technologies over the last few years; however, several obstacles still remain impeding translation of this exploding area of research into clinical care. One such challenge is lack of standardization of sample selection, collection, storage, handling, and conducting microbiome research (Santiago et al. 2014). Together with high intra- and interpersonal variability, complexity and abundance of outcomes, and high cost for sequencing and analyses small changes in any of these protocols can lead to huge differences in results. More importantly, bio-informatics and analyses of the tremendously complex datasets produced by this research lead to either superficial summarization of findings (and loss of detail) or complex, difficult to present and understand results (which only few can truly make sense of). An additional challenge is that much of the mechanistic insight into these complex conditions is derived from murine models; therefore, more humanbased research is required to avoid over interpretation of disease models, which fail in many cases to translate into clinical care (Perrin 2014). The future will likely involve computer-assisted tools to define microbial themes in individual patients. This will enable harnessing bacteria to benefit patients with IBD and other immune-mediated conditions. Current treatment strategies focused on altering microbes, and responses to them are therefore limited; however, as research tools are further advanced and developed, microbial composition, functional research, and mechanistic insights into host-microbe interactions will enable personalization of management of IBD patients and development of novel treatment approaches.

\section{REFERENCES}

Alipour, M., Lou, Y., Zimmerman, D., Bording-Jorgensen, M.W., Sergi, C., Liu, J.J., and Wine, E. 2013. A balanced IL-1beta activity is required for host response to Citrobacter rodentium infection. PLoS One. 8:e80656. PMID: 24312491. doi: 10.1371/journal.pone.0080656.

Anderson, J.L., Edney, R.J., and Whelan, K. 2012. Systematic review: faecal microbiota transplantation in the management of inflammatory bowel disease. Aliment. Pharmacol. Ther. 36:503-516. PMID: 22827693. doi: 10.1111/j.1365-2036.2012.05122.x.

Arthur, J.C., Perez-Chanona, E., Muhlbauer, M., Tomkovich, S., Uronis, J.M., Fan, T.J., Campbell, B. J., Abujamel, T., Dogan, B., Rogers, A.B., Rhodes, J.M., Stintzi, A., Simpson, K.W., Hansen, J.J., Keku, T.O., Fodor, A.A., and Jobin, C. 2012. Intestinal inflammation targets cancer-inducing activity of the microbiota. Science. 338:120-123. PMID: 22903521. doi: 10.1126/science.1224820. 
Arumugam, M., Raes, J., Pelletier, E., Le Paslier, D., Yamada, T., Mende, D.R., Fernandes, G.R., Tap, J., Bruls, T., Batto, J.M., Bertalan, M., Borruel, N., Casellas, F., Fernandez, L., Gautier, L., Hansen, T., Hattori, M., Hayashi, T., Kleerebezem, M., Kurokawa, K., Leclerc, M., Levenez, F., Manichanh, C., Nielsen, H.B., Nielsen, T., Pons, N., Poulain, J., Qin, J., Sicheritz-Ponten, T., Tims, S., Torrents, D., Ugarte, E., Zoetendal, E.G., Wang, J., Guarner, F., Pedersen, O., de Vos, W.M., Brunak, S., Doré, J., and MetaHIT Consortium. 2011. Enterotypes of the human gut microbiome. Nature. 473:174-180. PMID: 21508958. doi: 10.1038/nature09944.

Atarashi, K., Tanoue, T., Oshima, K., Suda, W., Nagano, Y., Nishikawa, H., Fukuda, S., Saito, T., Narushima, S., Hase, K., Kim, S., Fritz, J.V., Wilmes, P., Ueha, S., Matsushima, K., Ohno, H., Olle, B., Sakaguchi, S., Taniguchi, T., Morita, H., Hattori, M, and Honda, K. 2013. Treg induction by a rationally selected mixture of Clostridia strains from the human microbiota. Nature. 500:232-236. PMID: 23842501. doi: 10.1038/ nature12331.

Ayres, J.S. 2013. Inflammasome-microbiota interplay in host physiologies. Cell. Host. Microbe. 14:491-497. PMID: 24237695. doi: 10.1016/j.chom.2013.10.013.

Bach, J.F. 2002. The effect of infections on susceptibility to autoimmune and allergic diseases. N. Engl. J. Med. 347:911-920. PMID: 12239261. doi: 10.1056/ NEJMra020100.

Backhed, F., Fraser, C.M., Ringel, Y., Sanders, M.E., Sartor, R.B., Sherman, P.M., Versalovic, J., Young, V., and Finlay, B.B. 2012. Defining a healthy human gut microbiome: current concepts, future directions, and clinical applications. Cell. Host. Microbe. 12:611622. PMID: 23159051. doi: 10.1016/j.chom.2012. 10.012 .

Baxt, L.A., Garza-Mayers, A.C., and Goldberg, M.B. 2013. Bacterial subversion of host innate immune pathways. Science. 340:697-701. PMID: 23661751. doi: 10.1126/science.1235771.

Beamish, L.A., Osornio-Vargas, A.R., and Wine, E. 2011. Air pollution: an environmental factor contributing to intestinal disease. J. Crohns. Colitis. 5:279286. PMID: 21683297. doi: 10.1016/j.crohns.2011. 02.017.

Belcheva, A., Irrazabal, T., Robertson, S.J., Streutker, C., Maughan, H., Rubino, S., Moriyama, E.H., Copeland, J.K., Kumar, S., Green, B., Geddes, K., Pezo, R.C., Navarre, W.W., Milosevic, M., Wilson, B.C., Girardin, S.E., Wolever, T.M., Edelmann, W., Guttman, D.S., Philpott, D.J., and Martin, A. 2014. Gut microbial metabolism drives transformation of msh2-deficient colon epithelial cells. Cell. 158:288-299. PMID: 25036629. doi: 10.1016/j.cell.2014.04.051.

Belkaid, Y., and Hand, T.W. 2014. Role of the microbiota in immunity and inflammation. Cell. 157:121141. PMID: 24679531. doi: 10.1016/j.cell.2014.03.011. Benjamin, J.L., Sumpter, R. Jr., Levine, B., and Hooper, L.V. 2013. Intestinal epithelial autophagy is essential for host defense against invasive bacteria. Cell. Host. Microbe. 13:723-734. PMID: 23768496. doi: 10.1016/ j.chom.2013.05.004.

Brandl, K., Plitas, G., Mihu, C.N., Ubeda, C., Jia, T., Fleisher, M., Schnabl, B., DeMatteo, R.P., and Pamer, E.G. 2008. Vancomycin-resistant enterococci exploit antibiotic-induced innate immune deficits. Nature. 455:804-807. PMID: 18724361. doi: 10.1038/nature 07250.

Cadwell, K., Patel, K.K., Maloney, N.S., Liu, T.C., Ng, A. C., Storer, C.E., Head, R.D., Xavier, R., Stappenbeck, T.S., and Virgin, H.W. 2010. Virus-plus-susceptibility gene interaction determines Crohn's disease gene Atg16L1 phenotypes in intestine. Cell. 141:11351145. PMID: 20602997. doi: 10.1016/j.cell.2010. 05.009.

Camilleri, M., Madsen, K., Spiller, R., Greenwood-Van Meerveld, B., and Verne, G.N. 2012. Intestinal barrier function in health and gastrointestinal disease. Neurogastroenterol. Motil. 24:503-512. PMID: 22583600. doi: 10.1111/j.1365-2982.2012.01921.x.

Castiglione, F., Diaferia, M., Morace, F., Labianca, O., Meucci, C., Cuomo, A., Panarese, A., Romano, M., Sorrentini, I., D'Onofrio, C., Caporaso, N., and Rispo, A. 2012. Risk factors for inflammatory bowel diseases according to the "hygiene hypothesis": a casecontrol, multi-centre, prospective study in Southern Italy. J. Crohns. Colitis. 6:324-329. PMID: 22405169. doi: 10.1016/j.crohns.2011.09.003.

Chassaing, B., Koren, O., Carvalho, F.A., Ley, R.E., and Gewirtz, A.T. 2014. AIEC pathobiont instigates chronic colitis in susceptible hosts by altering microbiota composition. Gut. 63:1069-1080. PMID: 23896971. doi: 10.1136/gutjnl-2013-304909.

Chen, R., Mias, G.I., Li-Pook-Than, J., Jiang, L., Lam, H.Y., Chen, R., Miriami, E., Karczewski, K.J., Hariharan, M., Dewey, F.E., Cheng, Y., Clark, M.J., Im, H., Habegger, L., Balasubramanian, S., O'Huallachain, M., Dudley, J.T., Hillenmeyer, S., Haraksingh, R., Sharon, D., Euskirchen, G., Lacroute, P., Bettinger, K., Boyle, A.P., Kasowski, M., Grubert, F., Seki, S., Garcia, M., Whirl-Carrillo, M., Gallardo, M., Blasco, M.A., Greenberg, P.L., Snyder, P., Klein, T.E., Altman, R.B., Butte, A.J., Ashley, E.A., Gerstein, M., Nadeau, K.C., Tang, H., and Snyder, M. 2012. Personal omics 
profiling reveals dynamic molecular and medical phenotypes. Cell. 148:1293-1307. PMID: 22424236. doi: 10.1016/j.cell.2012.02.009.

Chiu, I.M., Heesters, B.A., Ghasemlou, N., Von Hehn, C.A., Zhao, F., Tran, J., Wainger, B., Strominger, A., Muralidharan, S., Horswill, A.R., Bubeck Wardenburg, J., Hwang, S.W., Carroll, M.C., and Woolf, C.J. 2013. Bacteria activate sensory neurons that modulate pain and inflammation. Nature. 501:52-57. PMID: 23965627. doi: 10.1038/nature12479.

Chu, K.M., Watermeyer, G., Shelly, L., Janssen, J., May, T.D., Brink, K., Benefeld, G., and Li, X. 2013. Childhood helminth exposure is protective against inflammatory bowel disease: a case control study in South Africa. Inflamm. Bowel. Dis. 19:614-620. PMID: 23380935. doi: 10.1097/MIB.0b013e31827f27f4.

Corridoni, D., Arseneau, K., and Cominelli, F. 2014. Functional defects in NOD2 signaling in experimental and human Crohn Disease. Gut. Microbes. 5:340-344. PMID: 24637801. doi: 10.4161/gmic.28404.

Cupi, M.L., Sarra, M., Marafini, I., Franzè, E., Ortenzi, A., Colantoni, A., Sica, G., Sileri, P., Rosado, M.M., Carsetti, R., MacDonald, T.T., Pallone, F., and Monteleone, G. 2014. Plasma cells in the mucosa of patients with inflammatory bowel disease produce granzyme B and possess cytotoxic activities. J. Immunol. 192:6083-6091. PMID: 24835396. doi: 10.4049/ jimmunol.1302238.

Czuczman, M.A., Fattouh, R., van Rijn, J.M., Canadien, V., Osborne, S., Muise, A.M., Kuchroo, V.K., Higgins, D.E., and Brumell, J.H. 2014. Listeria monocytogenes exploits efferocytosis to promote cell-to-cell spread. Nature. 509:230-234. PMID: 24739967. doi: 10.1038/ nature13168.

Dalmasso, M., Hill, C., and Ross, R.P. 2014. Exploiting gut bacteriophages for human health. Trends. Microbiol. 22:399-405. PMID: 24656964. doi: 10.1016/j. tim.2014.02.010.

D’Argenio, V., Precone, V., Casaburi, G., et al. 2013. An altered gut microbiome profile in a child affected by Crohn's disease normalized after nutritional therapy. Am. J. Gastroenterol. 108:851-852. PMID: 23644964. doi: 10.1038/ajg.2013.46.

David, L.A., Maurice, C.F., Carmody, R.N., Gootenberg, D.B., Button, J.E., Wolfe, B.E., Ling, A.V., Devlin, A.S., Varma, Y., Fischbach, M.A., Biddinger, S.B., Dutton, R.J., and Turnbaugh, P.J. 2014. Diet rapidly and reproducibly alters the human gut microbiome. Nature. 505:559-563. PMID: 24336217. doi: 10.1038/ nature12820.

Deuring, J.J., Fuhler, G.M., Konstantinov, S.R., Peppelenbosch, M.P., Kuipers, E.J., de Haar, C., and van der Woude, C.J. 2014. Genomic ATG16L1 risk allele-restricted Paneth cell ER stress in quiescent Crohn's disease. Gut. 63:1081-1091. PMID: 23964099. doi: 10.1136/gutjnl-2012-303527.

Devkota, S., Wang, Y., Musch, M.W., Leone, V., FehlnerPeach, H., Nadimpalli, A., Antonopoulos, D.A., Jabri, B., and Chang, E.B. 2012. Dietary-fat-induced taurocholic acid promotes pathobiont expansion and colitis in Il10-/- mice. Nature. 487:104-108. PMID: 22722865.

D'Haens, G.R., Geboes, K., Peeters, M., Baert, F., Penninckx, F., and Rutgeerts, P. 1998. Early lesions of recurrent Crohn's disease caused by infusion of intestinal contents in excluded ileum. Gastroenterology. 114:262-267. doi: 10.1016/S0016-5085(98) 70476-7.

Ding, T., and Schloss, P.D. 2014. Dynamics and associations of microbial community types across the human body. Nature. 509:357-560. PMID: 24739969. doi: 10.1038/nature13178.

Eckburg, P.B., Bik, E.M., Bernstein, C.N., Purdom, E., Dethlefsen, L., Sargent, M., Gill, S.R., Nelson, K.E., and Relman, D.A. 2005. Diversity of the human intestinal microbial flora. Science. 308:1635-1638. PMID: 15831718. doi: 10.1126/science.1110591.

Everard, A., Belzer, C., Geurts, L., Ouwerkerk, J.P., Druart, C., Bindels, L.B., Guiot, Y., Derrien, M., Muccioli, G.G., Delzenne, N.M., de Vos, W.M., and Cani, P.D. 2013. Cross-talk between Akkermansia muciniphila and intestinal epithelium controls diet-induced obesity. Proc. Natl. Acad. Sci. USA. 110:9066-9071. PMID: 23671105. doi: 10.1073/pnas.1219451110.

Gareau, M.G., Wine, E., Reardon, C., and Sherman, P. M. 2010. Probiotics prevent death caused by Citrobacter rodentium infection in neonatal mice. J. Infect. Dis. 201:81-91. PMID: 19961304. doi: 10.1086/ 648614.

Garg, S.K., Croft, A.M., and Bager, P. 2014. Helminth therapy (worms) for induction of remission in inflammatory bowel disease. Cochrane. Database. Syst. Rev. 1:CD009400. PMID: 24442917.

Garrett, W.S., Lord, G.M., Punit, S., Lugo-Villarino, G., Mazmanian, S.K., Ito, S., Glickman, J.N., and Glimcher, L.H. 2007. Communicable ulcerative colitis induced by T-bet deficiency in the innate immune system. Cell. 131:33-45. PMID: 17923086. doi: 10.1016/j.cell.2007.08.017.

Gevers, D., Knight, R., Petrosino, J.F., Huang, K., McGuire, A.L., Birren, B.W., Nelson, K.E., White, O., Methé, B.A., and Huttenhower, C. 2012. The human microbiome project: a community resource for the 
healthy human microbiome. PLoS Biol. 10:e1001377. PMID: 22904687. doi: 10.1371/journal.pbio.1001377. Goodrich, J.K., Di Rienzi, S.C., Poole, A.C., Koren, O., Walters, W.A., Caporaso, J.G., Knight, R., and Ley, R.E. 2014. Conducting a microbiome study. Cell. 158:250-262. PMID: 25036628. doi: 10.1016/j.cell. 2014.06.037.

Gouba, N., Raoult, D., and Drancourt, M. 2014. Eukaryote culturomics of the gut reveals new species. PLoS One. 9:e106994. PMID: 25210972. doi: 10.1371/ journal.pone.0106994.

Hussey, S., Travassos, L.H., and Jones, N.L. 2009. Autophagy as an emerging dimension to adaptive and innate immunity. Semin Immunol. 21:233-41. PMID: 19502083. doi: 10.1016/j.smim.2009.05.004.

Huynh, H.Q., deBruyn, J., Guan, L., Diaz, H., Li, M., Girgis, S., Turner, J., Fedorak, R., and Madsen, K. 2009. Probiotic preparation VSL\#3 induces remission in children with mild to moderate acute ulcerative colitis: a pilot study. Inflamm. Bowel. Dis. 15:760768. PMID: 19067432. doi: 10.1002/ibd.20816.

Jostins, L., Ripke, S., Weersma, R.K., Duerr, R.H., McGovern, D.P., Hui, K.Y., Lee, J.C., Schumm, L.P., Sharma, Y., Anderson, C.A., Essers, J., Mitrovic, M., Ning, K., Cleynen, I., Theatre, E., Spain, S.L., Raychaudhuri, S., Goyette, P., Wei, Z., Abraham, C., Achkar, J.P., Ahmad, T., Amininejad, L., Ananthakrishnan, A.N., Andersen, V., Andrews, J.M., Baidoo, L., Balschun, T., Bampton, P.A., Bitton, A., Boucher, G., Brand, S., Büning, C., Cohain, A., Cichon, S., D’Amato, M., De Jong, D., Devaney, K.L., Dubinsky, M., Edwards, C., Ellinghaus, D., Ferguson, L.R., Franchimont, D., Fransen, K., Gearry, R., Georges, M., Gieger, C., Glas, J., Haritunians, T., Hart, A., Hawkey, C., Hedl, M., Hu, X., Karlsen, T.H., Kupcinskas, L., Kugathasan, S., Latiano, A., Laukens, D., Lawrance, I.C., Lees, C.W., Louis, E., Mahy, G., Mansfield, J., Morgan, A.R., Mowat, C., Newman, W., Palmieri, O., Ponsioen, C.Y., Potocnik, U., Prescott, N.J., Regueiro, M., Rotter, J.I., Russell, R.K., Sanderson, J. D., Sans, M., Satsangi, J., Schreiber, S., Simms, L.A., Sventoraityte, J., Targan, S.R., Taylor, K.D., Tremelling, M., Verspaget, H.W., De Vos, M., Wijmenga, C., Wilson, D.C., Winkelmann, J., Xavier, R.J., Zeissig, S., Zhang, B., Zhang, C.K., and Zhao, H. International IBD Genetics Consortium (IIBDGC). 2012. Hostmicrobe interactions have shaped the genetic architecture of inflammatory bowel disease. Nature. 491: 119-124. PMID: 23128233. doi: 10.1038/nature11582. Kao, D., Hotte, N., Gillevet, P., and Madsen, K. 2014. Fecal microbiota transplantation inducing remission in Crohn's colitis and the associated changes in fecal microbial profile. J. Clin. Gastroenterol. 48:625-628. PMID: 24667590. doi: 10.1097/ MCG.0000000000000131.

Khan, K.J., Ullman, T.A., Ford, A.C., Abadir, A., Marshall, J.K., Talley, N.J., and Moayyedi, P. 2011. Antibiotic therapy in inflammatory bowel disease: a systematic review and meta-analysis. Am. J. Gastroenterol. 106:661-673. PMID: 21407187. doi: 10.1038/ ajg.2011.72.

Klapproth, J.M., Sasaki, M., Sherman, M., Babbin, B., Donnenberg, M.S., Fernandes, P.J., Scaletsky, I.C., Kalman, D., Nusrat, A., and Williams, I.R. 2005. Citrobacter rodentium lifA/efal is essential for colonic colonization and crypt cell hyperplasia in vivo. Infect. Immun. 73:1441-1451. PMID: 15731042. doi: 10.1128/IAI.73.3.1441-1451.2005.

Knights, D., Lassen, K.G., and Xavier, R.J. 2013. Advances in inflammatory bowel disease pathogenesis: linking host genetics and the microbiome. Gut. 62:1505-1510. PMID: 24037875. doi: 10.1136/gutjnl2012-303954.

Knutson, C.G., Mangerich, A., Zeng, Y., Raczynski, A. R., Liberman, R.G., Kang, P., Ye, W., Prestwich, E. G., Lu, K., Wishnok, J.S., Korzenik, J.R., Wogan, G. N., Fox, J.G., Dedon, P.C., and Tannenbaum, S.R. 2013. Chemical and cytokine features of innate immunity characterize serum and tissue profiles in inflammatory bowel disease. Proc. Natl. Acad. Sci. USA. 110:E2332-E2341. PMID: 23754421. doi: 10.1073/ pnas. 1222669110.

Kostic, A.D., Xavier, R.J., and Gevers, D. 2014. The microbiome in inflammatory bowel disease: current status and the future ahead. Gastroenterology. 146:1489-1499. PMID: 24560869. doi: 10.1053/j. gastro.2014.02.009.

Kunde, S., Pham, A., Bonczyk, S., Crumb, T., Duba, M., Conrad, H. Jr., Cloney, D., and Kugathasan, S. 2013. Safety, tolerability, and clinical response after fecal transplantation in children and young adults with ulcerative colitis. J. Pediatr. Gastroenterol. Nutr. 56:597-601. PMID: 23542823. doi: 10.1097/ MPG.0b013e318292fa0d.

Lamkanfi, M., and Dixit, V.M. 2014. Mechanisms and functions of inflammasomes. Cell. 157:1013-1022. PMID: 24855941. doi: 10.1016/j.cell.2014.04.007.

Larsson, E., Tremaroli, V., Lee, Y.S., Koren, O., Nookaew, I., Fricker, A., Nielsen, J., Ley, R.E., and Bäckhed, F. 2012. Analysis of gut microbial regulation of host gene expression along the length of the gut and regulation of gut microbial ecology through MyD88. Gut. 61:1124-1131. PMID: 22115825. doi: 10.1136/ gutjnl-2011-301104. 
Lassen, K.G., Kuballa, P., Conway, K.L., Patel, K.K., Becker, C.E., Peloquin, J.M., Villablanca, E.J., Norman, J.M., Liu, T.C., Heath, R.J., Becker, M.L., Fagbami, L., Horn, H., Mercer, J., Yilmaz, O.H., Jaffe, J. D., Shamji, A.F., Bhan, A.K., Carr, S.A., Daly, M.J., Virgin, H.W., Schreiber, S.L., Stappenbeck, T.S., and Xavier, R.J. 2014. Atg16L1 T300A variant decreases selective autophagy resulting in altered cytokine signaling and decreased antibacterial defense. Proc. Natl. Acad. Sci. USA. 111:7741-7746. PMID: 24821797. doi: 10.1073/pnas.1407001111.

Levine, A., Griffiths, A., Markowitz, J., Wilson, D.C., Turner, D., Russell, R.K., Fell, J., Ruemmele, F.M., Walters, T., Sherlock, M., Dubinsky, M., and Hyams, J.S. 2011. Pediatric modification of the Montreal classification for inflammatory bowel disease: the Paris classification. Inflamm. Bowel. Dis. 17:1314-1321. PMID: 21560194. doi: 10.1002/ibd.21493.

Levine, A., and Turner, D. 2011. Combined azithromycin and metronidazole therapy is effective in inducing remission in pediatric Crohn's disease. J. Crohns colitis. 5:222-226. PMID: 21575885. doi: 10.1016/j. crohns.2011.01.006.

Levine, A., and Wine, E. 2013. Effects of enteral nutrition on Crohn's disease: clues to the impact of diet on disease pathogenesis. Inflamm. Bowel. Dis. 19:1322-1329. PMID: 23399738. doi: 10.1097/MIB. 0b013e3182802acc.

Li, J., Jia, H., Cai, X., Zhong, H., Feng, Q., Sunagawa, S., Arumugam, M., Kultima, J.R., Prifti, E., Nielsen, T., Juncker, A.S., Manichanh, C., Chen, B., Zhang, W., Levenez, F., Wang, J., Xu, X., Xiao, L., Liang, S., Zhang, D., Zhang, Z., Chen, W., Zhao, H., Al-Aama, J.Y., Edris, S., Yang, H., Wang, J., Hansen, T., Nielsen, H.B., Brunak, S., Kristiansen, K., Guarner, F., Pedersen, O., Doré, J., and Ehrlich, S.D.MetaHIT Consortium. 2014. An integrated catalog of reference genes in the human gut microbiome. Nat. Biotechnol. 32:834-841. PMID: 24997786. doi: 10.1038/nbt.2942. Machiels, K., Joossens, M., Sabino, J., De Preter, V., Arijs, I., Eeckhaut, V., Ballet, V., Claes, K., Van Immerseel, F., Verbeke, K., Ferrante, M., Verhaegen, J., Rutgeerts, P., and Vermeire, S. 2014. A decrease of the butyrate-producing species Roseburia hominis and Faecalibacterium prausnitzii defines dysbiosis in patients with ulcerative colitis. Gut. 63:1275-1283. PMID: 24021287. doi: 10.1136/gutjnl-2013-304833.

Manichanh, C., Borruel, N., Casellas, F., and Guarner, F. 2012. The gut microbiota in IBD. Nat. Rev. Gastroenterol. Hepatol. 9:599-608. PMID: 22907164. doi: 10.1038/nrgastro.2012.152.
Markle, J.G., Frank, D.N., Mortin-Toth, S., Robertson, C.E., Feazel, L.M., Rolle-Kampczyk, U., von Bergen, M., McCoy, K.D., Macpherson, A.J., and Danska, J.S. 2013. Sex differences in the gut microbiome drive hormone-dependent regulation of autoimmunity. Science. 339:1084-1088. PMID: 23328391. doi: 10.1126/ science. 1233521.

Mayer-Barber, K.D., Andrade, B.B., Oland, S.D., Amaral, E.P., Barber, D.L., Gonzales, J., Derrick, S. C., Shi, R., Kumar, N.P., Wei, W., Yuan, X., Zhang, G., Cai, Y., Babu, S., Catalfamo, M., Salazar, A.M., Via, L.E., Barry, C.E. 3rd., and Sher, A. 2014. Hostdirected therapy of tuberculosis based on interleukin-1 and type I interferon crosstalk. Nature. 511:99-103. PMID: 24990750. doi: 10.1038/nature 13489.

Michail, S., Durbin, M., Turner, D., Griffiths, A.M., Mack, D.R., Hyams, J., Leleiko, N., Kenche, H., Stolfi, A., and Wine, E. 2012. Alterations in the gut microbiome of children with severe ulcerative colitis. Inflamm. Bowel. Dis. 18:1799-1808. PMID: 22170749. doi: 10.1002/ibd.22860.

Muller, P.A., Koscso, B., Rajani, G.M., Stevanovic, K., Berres, M.L., Hashimoto, D., Mortha, A., Leboeuf, M., Li, X.M., Mucida, D., Stanley, E.R., Dahan, S., Margolis, K.G., Gershon, M.D., Merad, M., and Bogunovic, M. 2014. Crosstalk between muscularis macrophages and enteric neurons regulates gastrointestinal motility. Cell. 158:300-313. PMID: 250 36630. doi: 10.1016/j.cell.2014.08.002. doi: 10.1016/j. cell.2014.04.050.

Neurath, M.F. 2014. Cytokines in inflammatory bowel disease. Nat. Rev. Immunol. 14:329-342. PMID: 24751956. doi: 10.1038/nri3661.

Ng, S.C., Bernstein, C.N., Vatn, M.H., Lakatos, P.L., Loftus, E.V. Jr., Tysk, C., O’Morain, C., Moum, B., and Colombel, J.F. Epidemiology and Natural History Task Force of the International Organization of Inflammatory Bowel Disease (IOIBD). 2013. Geographical variability and environmental risk factors in inflammatory bowel disease. Gut. 62:630-649. PMID: 23335431. doi: 10.1136/gutjnl-2012-303661.

Nicholson, J.K., Holmes, E., Kinross, J., Burcelin, R., Gibson, G., Jia, W., and Pettersson, S. 2012. Host-gut microbiota metabolic interactions. Science. 336: 1262-1267. PMID: 22674330. doi: 10.1126/science. 1223813.

O’Hara, A.M., O’Regan, P., Fanning, A., O’Mahony, C., Macsharry, J., Lyons, A., Bienenstock, J., O’Mahony, L., and Shanahan, F. 2006. Functional modulation of human intestinal epithelial cell responses by Bifidobacterium infantis and Lactobacillus salivarius. 
Immunology. 118:202-215. PMID: 16771855. doi: 10.1111/j.1365-2567.2006.02358.x.

Osborne, L.C., Monticelli, L.A., Nice, T.J., Sutherland, T. E., Siracusa, M.C., Hepworth, M.R., Tomov, V.T., Kobuley, D., Tran, S.V., Bittinger, K., Bailey, A.G., Laughlin, A.L., Boucher, J.L., Wherry, E.J., Bushman, F.D., Allen, J.E., Virgin, H.W., and Artis, D. 2014. Coinfection. Virus-helminth coinfection reveals a microbiota-independent mechanism of immunomodulation. Science. 345:578-582. PMID: 25082704. doi: 10.1126/ science.1256942.

Perez-Cobas, A.E., Gosalbes, M.J., Friedrichs, A., Knecht, H., Artacho, A., Eismann, K., Otto, W., Rojo, D., Bargiela, R., von Bergen, M., Neulinger, S.C., Däumer, C., Heinsen, F.A., Latorre, A., Barbas, C., Seifert, J., dos Santos, V.M., Ott, S.J., Ferrer, M., and Moya, A. 2013. Gut. microbiota disturbance during antibiotic therapy: a multi-omic approach. Gut. 62:1591-1601. PMID: 23236009. doi: 10.1136/gutjnl2012-303184.

Perrin, S. 2014. Preclinical research: make mouse studies work. Nature. 507:423-425. PMID: 24678540. doi: $10.1038 / 507423 a$.

Peterson, D.A., Frank, D.N., Pace, N.R., and Gordon, J.I. 2008. Metagenomic approaches for defining the pathogenesis of inflammatory bowel diseases. Cell. Host. Microbe. 3:417-427. PMID: 18541218. doi: 10.1016/j.chom.2008.05.001.

Peterson, L.W., and Artis, D. 2014. Intestinal epithelial cells: regulators of barrier function and immune homeostasis. Nat. Rev. Immunol. 14:141-153. PMID: 24566914. doi: 10.1038/nri3608.

Qin, J., Li, R., Raes, J., Burgdorf, K.S., Manichanh, C., Nielsen, T., Pons, N., Levenez, F., Yamada, T., Mende, D.R., Li, J., Xu, J., Li, S., Li, D., Cao, J., Wang, B., Liang, H., Zheng, H., Xie, Y., Tap, J., Lepage, P., Bertalan, M., Batto, J.M., Hansen, T., Le Paslier, D., Linneberg, A., Nielsen, H.B., Pelletier, E., Renault, P., Sicheritz-Ponten, T., Turner, K., Zhu, H., Yu, C., Li, S., Jian, M., Zhou, Y., Li, Y., Zhang, X., Li, S., Qin, N., Yang, H., Wang, J., Brunak, S., Doré, J., Guarner, F., Kristiansen, K., Pedersen, O., Parkhill, J., Weissenbach, J., MetaHIT Consortium, Bork, P., Ehrlich, S.D., and Wang, J. 2010. A human gut microbial gene catalogue established by metagenomic sequencing. Nature. 464:59-65. PMID: 20203603. doi: 10.1038/ nature 08821.

Ratsimandresy, R.A., Dorfleutner, A., and Stehlik, C. 2013. An update on PYRIN domain-containing pattern recognition receptors: from immunity to pathology. Front. Immunol. 4:440. PMID: 24367371. doi: 10.3389/fimmu.2013.00440.

Reese, T.A., Wakeman, B.S., Choi, H.S., Hufford, M.M., Huang, S.C., Zhang, X., Buck, M.D., Jezewski, A., Kambal, A., Liu, C.Y., Goel, G., Murray, P.J., Xavier, R.J., Kaplan, M.H., Renne, R., Speck, S.H., Artyomov, M.N., Pearce, E.J., and Virgin, H.W. 2014. Coinfection. Helminth infection reactivates latent gamma-herpesvirus via cytokine competition at a viral promoter. Science. 345:573-577. PMID: 24968940. doi: 10.1126/ science. 1254517.

Ridaura, V.K., Faith, J.J., Rey, F.E., Cheng, J., Duncan, A. E., Kau, A.L., Griffin, N.W., Lombard, V., Henrissat, B., Bain, J.R., Muehlbauer, M.J., Ilkayeva, O., Semenkovich, C.F., Funai, K., Hayashi, D.K., Lyle, B. J., Martini, M.C., Ursell, L.K., Clemente, J.C., Van Treuren, W., Walters, W.A., Knight, R., Newgard, C.B., Heath, A.C., and Gordon, J.I. 2013. Gut microbiota from twins discordant for obesity modulate metabolism in mice. Science. 341. PMID: 24009397. doi: 10.1126/science.1241214.

Roca, F.J., and Ramakrishnan, L. 2013. TNF dually mediates resistance and susceptibility to mycobacteria via mitochondrial reactive oxygen species. Cell. 153:521-534. PMID: 23582643. doi: 10.1016/j.cell. 2013.03.022.

Santaolalla, R., and Abreu, M.T. 2012. Innate immunity in the small intestine. Curr. Opin. Gastroenterol. 28:124-129. PMID: 22241076. doi: 10.1097/MOG. 0b013e3283506559.

Santiago, A., Panda, S., Mengels, G., Martinez, X., Azpiroz, F., Dore, J., Guarner, F., and Manichanh, C. 2014. Processing faecal samples: a step forward for standards in microbial community analysis. BMC Microbiol. 14:112. PMID: 24884524. doi: 10.1186/ 1471-2180-14-112.

Sartor, R.B. 2008. Microbial influences in inflammatory bowel diseases. Gastroenterology. 134:577-594. PMID: 18242222. doi: 10.1053/j.gastro.2007.11.059.

Shan, M., Gentile, M., Yeiser, J.R., Walland, A.C., Bornstein, V.U., Chen, K., He, B., Cassis, L., Bigas, A., Cols, M., Comerma, L., Huang, B., Blander, J.M., Xiong, H., Mayer, L., Berin, C., Augenlicht, L.H., Velcich, A., and Cerutti, A. 2013. Mucus enhances gut homeostasis and oral tolerance by delivering immunoregulatory signals. Science. 342:447-453. PMID: 24072822. doi: 10.1126/science. 1237910.

Shanahan, F. 2000. Probiotics and inflammatory bowel disease: is there a scientific rationale? Inflamm. Bowel. Dis. 6:107-115. PMID: 10833070. doi: 10.1097/ 00054725-200005000-00007. 
Shanahan, F. 2012. The gut microbiota-a clinical perspective on lessons learned. Nat. Rev. Gastroenterol. Hepatol. 9:609-614. PMID: 22890109. doi: 10.1038/ nrgastro.2012.145.

Shanahan, M.T., Carroll, I.M., Grossniklaus, E., White, A., von Furstenberg, R.J., Barner, R., Fodor, A.A., Henning, S.J., Sartor, R.B., and Gulati, A.S. 2014. Mouse Paneth cell antimicrobial function is independent of Nod2. Gut. 63:903-910. PMID: 23512834. doi: 10.1136/gutjnl-2012-304190.

Shaw, S.Y., Blanchard, J.F., and Bernstein, C.N. 2010. Association between the use of antibiotics in the first year of life and pediatric inflammatory bowel disease. Am. J. Gastroenterol. 105:2687-2692. PMID: 20940708. doi: 10.1038/ajg.2010.398.

Smith, M.I., Yatsunenko, T., Manary, M.J., Trehan, I., Mkakosya, R., Cheng, J., Kau, A.L., Rich, S.S., Concannon, P., Mychaleckyj, J.C., Liu, J., Houpt, E., Li, J.V., Holmes, E., Nicholson, J., Knights, D., Ursell, L.K., Knight, R., and Gordon, J.I. 2013. Gut microbiomes of Malawian twin pairs discordant for kwashiorkor. Science. 339:548-554. PMID: 23363771. doi: 10.1126/ science.1229000.

Smith, P.M., Howitt, M.R., Panikov, N., Michaud, M., Gallini, C.A., Bohlooly-Y, M., Glickman, J.N., and Garrett, W.S. 2013. The microbial metabolites, shortchain fatty acids, regulate colonic Treg cell homeostasis. Science. 341:569-573. PMID: 23828891. doi: $10.1126 /$ science. 1241165 .

Sokol, H., Pigneur, B., Watterlot, L., Lakhdari, O., Bermúdez-Humarán, L.G., Gratadoux, J.J., Blugeon, S., Bridonneau, C., Furet, J.P., Corthier, G., Grangette, C., Vasquez, N., Pochart, P., Trugnan, G., Thomas, G., Blottière, H.M., Doré, J., Marteau, P., Seksik, P., and Langella, P. 2008. Faecalibacterium prausnitzii is an anti-inflammatory commensal bacterium identified by gut microbiota analysis of Crohn disease patients. Proc. Natl. Acad. Sci. USA. 105:1673116736. PMID: 18936492. doi: 10.1073/pnas.08048 12105.

Tang, W.H., Wang, Z., Levison, B.S., Koeth, R.A., Britt, E.B., Fu, X., Wu, Y., and Hazen, S.L. 2013. Intestinal microbial metabolism of phosphatidylcholine and cardiovascular risk. N. Engl. J. Med. 368:1575-1584. PMID: 23614584. doi: 10.1056/NEJMoa1109400.

Tjellstrom, B., Hogberg, L., Stenhammar, L., Magnusson, K.E., Midtvedt, T., Norin, E., and Sundqvist, T. 2012. Effect of exclusive enteral nutrition on gut microflora function in children with Crohn's disease. Scand. J. Gastroenterol. 47:1454-1459. PMID: 23016828. doi: 10.3109/00365521.2012.703234.
Tobin, D.M., Roca, F.J., Oh, S.F., McFarland, R., Vickery, T.W., Ray, J.P., Ko, D.C., Zou, Y., Bang, N.D., Chau, T.T., Vary, J.C., Hawn, T.R., Dunstan, S.J., Farrar, J.J., Thwaites, G.E., King, M.C., Serhan, C.N., and Ramakrishnan, L. 2012. Host genotype-specific therapies can optimize the inflammatory response to mycobacterial infections. Cell. 148:434-446. PMID: 22304914. doi: 10.1016/j.cell.2011.12.023.

Tremaroli, V., and Backhed, F. 2012. Functional interactions between the gut microbiota and host metabolism. Nature. 489:242-249. PMID: 22972297. doi: 10.1038 /nature11552.

Turner, D., Levine, A., Kolho, K.L., Shaoul, R., and Ledder, O. 2014. Combination of oral antibiotics may be effective in severe pediatric ulcerative colitis: a preliminary report. J. Crohns. Colitis. 2014 in press. PMID: 24958064. doi: 10.1016/j.crohns.2014.05.010.

Vaishnava, S., Behrendt, C.L., Ismail, A.S., Eckmann, L., and Hooper, L.V. 2008. Paneth cells directly sense gut commensals and maintain homeostasis at the intestinal host-microbial interface. Proc. Natl. Acad. Sci. USA. 105:20858-20863. PMID: 19075245. doi: 10.1073/pnas.0808723105.

Vaishnava, S., Yamamoto, M., Severson, K.M., Ruhn, K.A., Yu, X., Koren, O., Ley, R., Wakeland, E.K., and Hooper, L.V. 2011. The antibacterial lectin RegIIIgamma promotes the spatial segregation of microbiota and host in the intestine. Science. 334:255-258. PMID: 21998396. doi: 10.1126/science.1209791.

VanDussen, K.L., Liu, T.C., Li, D., Towfic, F., Modiano, N., Winter, R., Haritunians, T., Taylor, K.D., Dhall, D., Targan, S.R., Xavier, R.J., McGovern, D.P., and Stappenbeck, T.S. 2014. Genetic variants synthesize to produce paneth cell phenotypes that define subtypes of Crohn's disease. Gastroenterology. 146:200209. PMID: 24076061. doi: 10.1053/j.gastro.2013. 09.048 .

van Nood, E., Vrieze, A., Nieuwdorp, M., Fuentes, S., Zoetendal, E.G., de Vos, W.M., Visser, C.E., Kuijper, E.J., Bartelsman, J.F., Tijssen, J.G., Speelman, P., Dijkgraaf, M.G., and Keller, J.J. 2013. Duodenal infusion of donor feces for recurrent Clostridium difficile. New Engl. J. Med. 368:407-415. PMID: 23323867. doi: 10.1056/NEJMoa1205037.

Veldhoen, M., and Heeney, J.L. 2014. A helminthmediated viral awakening. Trends. Immunol. 35: 452-453. PMID: 25174993. doi: 10.1016/j.it.2014. 08.004 .

Wesemann, D.R., Portuguese, A.J., Meyers, R.M., Gallagher, M.P., Cluff-Jones, K., Magee, J.M., Panchakshari, R.A., Rodig, S.J., Kepler, T.B., and Alt, F.W. 2013. Microbial colonization influences early B-lineage development 
in the gut lamina propria. Nature. 501:112-115. PMID: 23965619. doi: 10.1038/nature12496.

Whelan, K., and Quigley, E.M. 2013. Probiotics in the management of irritable bowel syndrome and inflammatory bowel disease. Curr. Opin. Gastroenterol. 29:184-189. PMID: 23286925. doi: 10.1097/MOG.0b0 $13 \mathrm{e} 32835 \mathrm{~d} 7 \mathrm{bba}$.

Wine, E. 2014. Should we be treating the bugs instead of cytokines and T cells? Dig. Dis. 32:403-409. PMID: 24969288. doi: 10.1159/000358146.

Wine, E., Mack, D.R., Hyams, J., Otley, A.R., Markowitz, J., Crandall, W.V., Leleiko, N., Muise, A.M., Griffiths, A.M., and Turner, D. 2013. Interleukin-6 is associated with steroid resistance and reflects disease activity in severe pediatric ulcerative colitis. J. Crohns. Colitis. 7:916-922. PMID: 23339932. doi: 10.1016/j. crohns.2012.12.012.

Winter, S.E., Winter, M.G., Xavier, M.N., Thiennimitr, P., Poon, V., Keestra, A.M., Laughlin, R.C., Gomez, G., Wu, J., Lawhon, S.D., Popova, I.E., Parikh, S.J., Adams, L.G., Tsolis, R.M., Stewart, V.J., and Bäumler, A.J. 2013. Host-derived nitrate boosts growth of $\mathrm{E}$. coli in the inflamed gut. Science. 339:708-711. PMID: 23393266. doi: 10.1126/science.1232467.

Wu, G.D., Chen, J., Hoffmann, C., Bittinger, K., Chen, Y.Y., Keilbaugh, S.A., Bewtra, M., Knights, D., Walters, W.A., Knight, R., Sinha, R., Gilroy, E., Gupta, K., Baldassano, R., Nessel, L., Li, H., Bushman, F.D., and Lewis, J.D. 2011. Linking long-term dietary patterns with gut microbial enterotypes. Science. 334:105-108. PMID: 21885731. doi: 10.1126/science.1208344.

Wu, G.D., and Lewis, J.D. 2013. Analysis of the human gut microbiome and association with disease. Clin. Gastroenterol. Hepatol. 11:774-777. PMID: 23643636. doi: 10.1016/j.cgh.2013.03.038.

Zhulina, Y., Hahn-Stromberg, V., Shamikh, A., Peterson, C.G., Gustavsson, A., Nyhlin, N., Wickbom, A., Bohr, J., Bodin, L., Tysk, C., Carlson, M., and Halfvarson, J. 2013. Subclinical inflammation with increased neutrophil activity in healthy twin siblings reflect environmental influence in the pathogenesis of inflammatory bowel disease. Inflamm. Bowel. Dis. 19:17251731. PMID: 23669399. 